\title{
Winter wonderland
}

\section{It may be cold and dark, but there's nowhere like Britain at Christmas time. Kate Craig says Merry Christmas.}

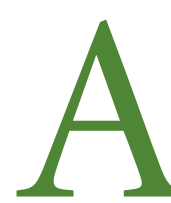

s December approaches and hopes of a last-minute escape to the sun fade, there is often only one bright spot on the rapidly darkening horizon...

the festive season.

Finding yourselves thrown into mid-winter is never fun, but if there's one time to be grateful it's winter... it's Christmas.

I'll never forget my first Northern Hemisphere Christmas. Having moved from New Zealand to London I wasn't looking forward to my first Christmas away from home... but sit soon became apparent I'd been missing out all these years.

The festivities began weeks before the big day. As festive music wafted through the airwaves, children stopped to sing carols outside my door, and department stores stacked their clothes racks full of party frocks, I knew something was different.

It all came to a head one night when one of my colleagues dragged me to Oxford Street to watch Ronan Keating turn on the Christmas lights. Having never heard of Boyzone (yes, it's true!) I wasn't very impressed with the thought of it, and the incessant cold (despite my first ever winter hat) didn't add much to my anticipation. But when the lights went on something clicked on inside me too.

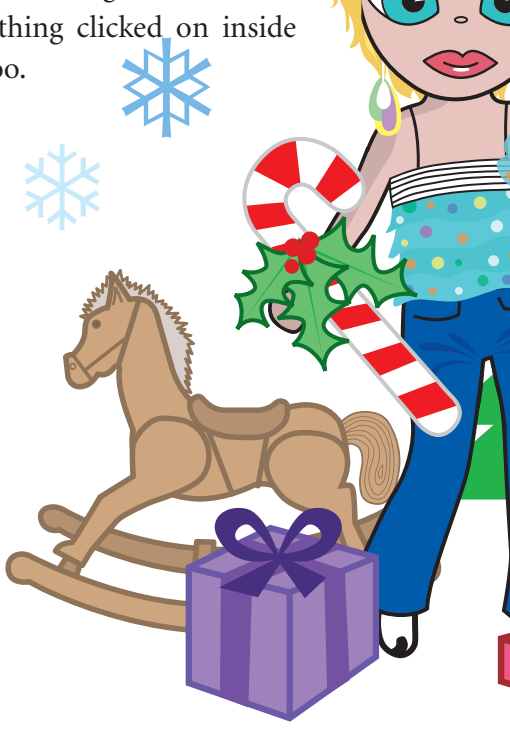

It was a couple of nights later that it began to snow in our backyard. Unfortunately for me, my boyfriend videoed the moment for posterity... a fully grown woman dancing around the bedroom, hands flying, crying 'it's snowing, it's snowing' with childlike glee in her eyes. The snow didn't settle, but it was good enough for me.

The next British winter tradition to observe was the famous work Christmas party. Veiled in secrecy, the theme was a topic of conversation for weeks. And I wasn't disappointed. The highlights included real mistletoe, my first taste of mulled wine and being introduced to a tasty morsel known as a pig-in-a-blanket. Even the appearance of 然

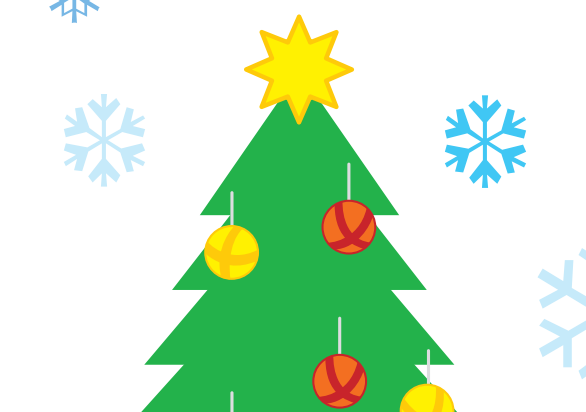

my arch nemesis, the brussel sprout, did little to dampen my spirits.

Secret Santa having made his not-so-secret annual appearance, the dancing began and the champagne flowed. Somehow afternoon drinking doesn't seem half as bad when it's pitch black by $4 \mathrm{pm}$.

By the time Christmas Day arrived I was ready to face it all again. Having joined my flatmates to carry a tree home from Homebase, decorated it with lights and sprayed snow on our windows, we were ready to celebrate. There was a lot to be said for a traditional Christmas.

It's not that we don't have Christmas trees at home in New Zealand, or work parties, or turkey or crackers. We do. Sometimes we put up Christmas lights too. But when it's hot, it's sunny, it's holiday season and the turkey's served cold with salad... somehow it's just not quite the same.

This Christmas I'll be back in New Zealand. I can't wait to share the day with my family and follow the traditions of my youth. But I'll be breaking out some mulled wine and making a toast to my British friends. Who knows, we might even have some brussel sprouts too. 